\title{
QUO VADIS THE ASEAN ROLE IN NATURAL DISASTER MANAGEMENT IN SOUTHEAST ASIA ${ }^{\Omega}$
}

\author{
Natalia Yeti Puspita \\ Faculty of Law, Universitas Katolik Indonesia Atma Jaya, Indonesia \\ E-mail: natalia.yp@atmajaya.ac.id
}

\begin{abstract}
The threats of natural disasters may happen anytime without recognizing national borders. Southeast Asia is an area which is prone to natural disasters. Every year ASEAN both as an international organization and its members encounter challenges to natural disaster management which is frequently beyond the country capability. This study is descriptive-analytic normative legal research which focuses on the secondary data as the main data. The finding of this study reveals that country is the main actor in natural disaster management based on primary state responsibility principles. The role of ASEAN is only limited to coordinate and facilitate cooperation among parties in providing humanitarian assistance when the natural disaster occurs. The aid has to get approval from the country which suffers from natural disaster. The role of ASEAN is conducted by AHA Center based on AADMER implemented on 2009.
\end{abstract}

Keywords: ASEAN, Southeast Asia, natural disaster management

\begin{abstract}
Abstrak
Ancaman bencana alam dapat terjadi setiap saat dan tidak mengenal batas negara. Asia Tenggara adalah kawasan yang rawan terhadap bencana alam. Setiap tahun ASEAN sebagai organisasi internasional dan juga negara-negara anggotanya dihadapkan pada tantangan untuk menanggulangi bencana alam yang kadang melebihi kapasitas nasional negara yang ada. Penelitian ini adalah penelitian hukum normatif yang bersifat deskriptif-analitis dan menekankan pada data sekunder sebagai data utama. Temuan penelitian, negara adalah aktor utama dalam penanggulangan bencana alam berdasarkan prinsip primary state responsibility. Peranan ASEAN masih sebatas sebagai koordinator dan fasilitator kerja sama para pihak dalam memberikan bantuan kemanusiaan pada saat terjadi bencana alam. Bantuan kemanusian harus mendapatkan persetujuan dari negara korban bencana alam. Peranan ASEAN dilaksanakan oleh AHA Center berdasarkan AADMER yang mulai diberlakukan pada tahun 2009.
\end{abstract}

Kata kunci: ASEAN, Asia Tenggara, penanggulangan bencana alam

\section{Introduction}

Nowadays, a country cannot stand on its own without interacting with others. It is done by establishing an international organization aimed to accommodate every country's interests. ${ }^{1}$ In Southeast Asia, there is an internatio-

$\Omega \quad$ This paper is a doctoral dissertation research 2016 fund ed by contract number DIPA: SP DIPA-042.04.01.400170/ 2016 on December $7^{\text {th }}, 2015$. Letter of Agreement on Implementation of Research for Private Higher Education Staff of Kopertis Region III on 2016 No. 769/K3/KM/ SPK.LT/2016 on June $14^{\text {th }}$, 2016 and Letter of Agreement on Appointment to Implement Research Program on 2016 Unika Atma Jaya No. 628/III/LPPM-HD/07/2016.

Lesza Leonardo Lombok, "Kedaulatan Negara vis a vis Keistimewaan dan Kekebalan Hukum Organisasi Internasional dalam Sebuah Intervensi Kemanusiaan”, Jurnal nal organization called ASEAN (Association of Southeast Asian Nations). ${ }^{2}$

Southeast Asia region, which consists of Indonesia, Singapore, Brunei Darussalam, Malaysia, Vietnam, Cambodia, Thailand, Myanmar, Laos and Timor Leste, are areas prone to natural disasters. ${ }^{3}$ According to data from the Inter-

Pandecta, Vol. 9 Issue 1, January, 2014, Semarang: Universitas Negeri Semarang, page 51.

2 Donald K. Emmerson, "Security, Community, and Democracy in Southeast Asia: Analyzing ASEAN", Japanese Journal of Political Science, Vol. 6 Issue 2, 2008, United Kingdom: Cambridge University Press, page 165.

3 Gabrielle SIMM, "Disaster Response in Southeast Asia: the ASEAN Agreement on Disaster Response and Emergency Management", Asian Journal of International Law, 
national Disaster Database, they mentioned that during 2003 - 2013; 8.83 percent (177. 813. 938 people) of the world's population were affected by natural disasters in Southeast Asia region and has contributed to more than $31 \%$ ( 355.365 people) of global deaths due to natural disasters. ${ }^{4}$ For instance: firstly, on December 2004, Tsunami had resulted over 230,000 deaths in the Indian Ocean; secondly, a cyclone Nargis, occurred in Irrawaddy Delta in Myanmar on Friday, May $2^{\text {nd }} 2008$, had killed more than 140,000 people and caused catastrophic destruction and more than 2.4 million people need humanitarian assistance; ${ }^{5}$ thirdly, in June 2008, typhoon Fengshen struck Philippines, Hong Kong and Guangdong Provinces in southern China causing severe dam-ages and took at least 1000 lives while most of the passengers on the Princess of the Stars ferry were killed when the ferry capsized. ${ }^{6}$ Furthermore, on Saturday November $9^{\text {th }}, 2013$ the world was again stricken by the great natural disaster of "Typhoon Haiyan" in Leyte Province, Philippines and at that time Typhoon Haiyan was also heading to Vietnam. The losses suffered from natural disasters in Southeast Asia are more than $U \$ 4.4$ billion per year in the last decade. ${ }^{7}$

Natural disasters often occur on a large scale and in conflict areas such as in Aceh-Indonesia, Rakhine state (Rohingya ethnic region)Myanmar, and Mindanao-Philippines. Under these conditions, countries which suffer from the

doi:10.1017/S2044251316000205, 2016, Singapore: the National University of Singapore, page 5.

4 Daniel Petz, 2014, "Strengthening Regional and National Capacity for Disaster Risk Management-the Case of ASEAN", Brooking LSE Project on Internal Displacement. Brooking Institution, page 11 , available on website http://www. brookings.edu/ /media/research/files/rep orts/2014/11/05-south-east-asia-drmpetz/strengthening -regional-and-national-capacity-for-drm--case-of-aseannovember-5-2014.pdf, accessed on August 4, 2015; see on EM-DAT: The OFDA/CRED International Disaster Database.

5 Julie Belanger and Richard Horsey, "Negotiating Humanitarian Access to Cyclone-Affected Areas: a Review", Humanitarian Practice Network Journal, No. 41, December 2008, United Kingdom: Humanitarian Policy Group, page 2 .

6 Allen Hicken, “The Philippines in 2008: Peace Building, War-Fighting, and Crisis Management", Asian Survey Journal, Vol. 49 No. 1, January/February 2009,USA: University California Press, page 198.

7 Daniel Petz, Loc.Cit. natural disasters are often not ready or even fail to overcome the disaster. Thus, humanitarian assistance of external parties such as other countries, international organizations, and NonGovernmental Organizations (NGOs) is strongly expected. ${ }^{8}$ However, the process of requesting/ receiving humanitarian assistance often involving tensions due to the absence of good regulation and coordination between the recipient country and the aid provider country ${ }^{9}$ which is influenced by the strong implementation of state sovereignty principle and non-intervention by other ASEAN country members. This condition hampers the protection of rights of natural disaster victims.

A good coordination between parties is required to achieve the aid effectiveness and right fulfillment of natural disaster victims. In the midst of vagueness to the implementation of state sovereignty principle and non-intervention principle in the process of granting/ receiving humanitarian assistance during natural disaster emergency response, the presence of ASEAN as an international regional organization has brought a fresh air in solving the problem. In this research, the researcher describes the results of research on the quo vadis the role of ASEAN on natural disaster management in Southeast Asia.

\section{Problems}

Based on the background above, the main research question for the study is how ASEAN plays its role in managing natural disaster in Southeast Asia? The researcher will examine the main research question into two sub-issues as follows: first, ASEAN's regulation to natural disasters in Southeast Asia; and second, the implementation of natural disaster management by ASEAN in Southeast Asia region.

8 Dorothea Hilhorst and Bram J. Jansen, "Humanitarian Space as Arena: A Perspective on the Everyday Politics of Aid", Development and Change Journal, Vol. 41 Issue 6, November 2010, The Hague: International Institute of Social Studies, page 1136.

9 Natsri Anshari, "Harmonisasi Hukum Internasional dan Hukum Nasional dalam Bantuan Kemanusiaan dan Penanggulangan Bencana Alam", Jurnal Hukum Militer, Vol. 1 Issue 7, 2013, Jakarta: Pusat Studi Hukum MiliterSekolah Tinggi Hukum Militer, page 19. 


\section{Research Method}

This research is a descriptive-analytical normative legal research. Normative legal research is done by studying secondary data and the analysis is descriptive. This research emphasizes secondary data as the main data and the data was obtained through library research. In order to support secondary data, primary data collection was conducted by interviewing some speakers of AHA Center officer and the officer in ASEAN Secretariat (the Head of External Relation Directorate, the Head of Cross Cooperation Directorate-the Disaster Management \& Humanitarian Assistance Division). The analysis was conducted on two research variables: Variable one (1)/bound variable: The Role of ASEAN; And Variable two (2)/dependent variable: natural disasters management in Southeast Asia.

\section{Discussion}

\section{ASEAN as Regional International Organization}

According to Peter Fischer, international organization is "a union or association of States, or of enterprises or of other national entities set up across national boundaries". ${ }^{10}$ Meanwhile, the definition of international organizations according to the International Law Commission (ILC) in the draft on the responsibility of international organizations is:

International organization means an organization established by a treaty or other instrument governed by international law and possessing its own international legal personality. International organizations may include as members, in addition to States, other entities. ${ }^{11}$

In this case, ILC added that, "If an international organization has no legal personality; it is not

10 Peter Fischer, 2012, “International Organization”, Vienna/Bratislava, page 9, available on website http:// paneurouni.com/files/sk/fp/ulohy-studentov/2rocnikbc /io-skript.1.10.2012.new-version.pdf, accessed on October $28^{\text {th }}, 2013$.

11 See Draft Articles on the Responsibility of International Organizations, Adopted by the International Law Commission at its sixty-third session, in 2011, Article 2 (a). Also see lan Huard, "Choice and Methods in the Study of International Organizations", Journal of International Organizations Studies, Vol. 2 Issues 2, 2011, United States of America: Brigham Young University-Kennedy Center, page 9. the organization but only the members that can be held responsible". ${ }^{12}$

Regional organizations are international organizations established according to geographical locations. ${ }^{13}$ ASEAN is one of the regional international organizations. Regionalism has become the issue of United Nations in Chapter VII of UN Charter.

Nowadays, regional international organizations have grown rapidly both in terms of quantity and scope of cooperation. There are at least more than 30 regional international organizations focusing on disaster management. ${ }^{14} \mathrm{It}$ indicates a significant improvement on the role of regional international organizations. In this current globalization era, regionalism can be an effective way or link between international and national systems. As Haver and Foley stated,

a regional entity working from cultural and linguistic commonalities, can provide a forum for building trust and familiarity that is not possible on a global scale. For these reasons, they can often be more effective in establishing common policies and resolving issues of contention. ${ }^{15}$

In addition, it can be noted that regional international organizations are often more coherent in accommodating the interests of states members and solving problems by consensus. In disaster mitigation framework, regional mechanisms cannot respond more quickly than other international mechanisms yet their interven-

12 See the First Report on Responsibility of International Organization by ILC Special Rapporteur Gaja, UN Doc.A/ CCN.4/532, at 15. Also see Simon Chesterman, "Does ASEAN Exist? The Associaton of Southeast Asian Nations as an International Legal Person", Singapore Year Book of International Law (SYBIL) Journal, Issue 12, 2010, Singapore: The National University of Singapore, page 200.

13 lbid.

14 Elizabeth Ferris and Daniel Petz, 2013, In the Neighborhood: the Growing Role of Regional Organizations in Disaster Risk Management, the Brooking Institution-London School of Economics Project on Internal Displacement, United Kingdom: the Brooking Institution-London School of Economics, page 1.

15 Katherine Haver and Conor Foley, "International and Regional Initiatives", Background paper 2 prepared for the International Dialogue on Strengthening Partnership in Disaster Response, 2011, available on website: http:// www. ifrc.org/PageFiles/93533/Background\%20paper\%20 2.pdf, accessed on November $5^{\text {th }}, 2014$. 
tions can also be politically more acceptable. Relating to this, Kati Suominen stated,

[r]egional organizations are particularly well-equipped to carry out today's threat management functions. They have solid information and expertise on their regions, inherently tailor their responses to the regional realities, and can get on the ground fast. ROs [regional organizations] are also innately compelled to continue their engagement and monitoring of the scene when the other actors depart. And having reshaped their policies and plans over the years to meet newly emerging challenges, ROs have a record of responsiveness and institutional flexibility. ${ }^{16}$

ASEAN was established on 8 August 1967 amid the changing regional and international situation. ${ }^{17}$ ASEAN was originally established for the sake of the Southeast Asian region security and was not intended to integrate the economic field of its member countries or to create supranational organizations. As revealed by Benny Teh Cheng Guan who stated that ASEAN's creation was initially for security. ${ }^{18}$ From 1967 to 2008, the interaction of ASEAN countries was based on the Bangkok Declaration or the ASEAN Declaration which is essentially a political statement that does not bind the rights and obligetions of states member and organizations on the basis of law/constitution. ${ }^{19}$ Since 2008, ASEAN has turned into an intergovernmental organization. This was reinforced by the enactment of the ASEAN Charter as the basic ASEAN Statute replacing the ASEAN Declaration on December 15, 2008 in Thailand at the 14th meeting of ASEAN Heads of State. ${ }^{20}$ The ASEAN Charter,

16 Kati Suominen, "Globalizing Regionalism: Harnessing Regional Organizations to Meet Global Threats", UNU-CRIS Occasional Papers, 2005, page 7, available on website http: / /www.cris.unu.edu/UNU-CRIS-Working-Papers, accessed on November $5^{\text {th }}, 2014$.

17 Benny Teh Cheng Guan, “ASEAN's Regional Challenge: The ASEAN Process", the Copenhagen Journal of Asian Studies, Vol. 20, 2004, Denmark: Asia Research CenterCopenhagen Business School, page 71

18 Ibid.

19 Elfia Farida,"Efektivitas Piagam ASEAN (ASEAN Charter) bagi ASEAN sebagai Organisasi Internasional”, Jurnal QISTIE, Vol. 3 Issue 3, 2009, Semarang: Faculty of Law Universitas Wahid Hasyim, page 1.

20 Termsak Chalermpalanupap, "the ASEAN Secretariat and Legal Issues Arising from ASEAN Charter”, Jurnal Hukum Internasional, Vol. 6 Issue 2, 2009, Depok: Lembaga signed on 20 November 2007 and ratified by all ASEAN member countries has de jure changed ASEAN from loose regional organizations into a rule-based organization. ${ }^{21}$

\section{Natural Disaster in Southeast Asia}

Natural disaster is a phenomenon possibly occurs in unpredictable time or situation. Here are the following data regarding the natural disasters that occur in the world and in Southeast Asia. Based on the data, it can be concluded that within 30 years there had been 10,376 natural disaster occurred and Asia as the region mostly stricken by natural disaster and suffered most losses than any other areas. In Asia, Southeast Asia is the region which is the most vulnerable to natural disasters.

\section{ASEAN Regulation on Natural Disaster Manage- ment in Southeast Asia Region}

To present, there is no comprehensive international legal instrument consisting of rules, principles and standards for the protection and efforts for natural disaster victims. Frequently, measures are conducted based on temporary and instant system and rules that show disparity between one country and another. AS a result, it does not guarantee a rapid and effective relief for victims, which ultimately puts life and human dignity at stake.

In practice, natural disaster management is carried out partially by each country. It is based on the principle of "primary state responsibility" that every country has sovereignty over the territory and its citizens. ${ }^{22}$ However, the matter of natural disaster management will become more problematic if natural disasters occur on a large scale and the affected country is unable or unwilling to provide assistance and

Pengkajian Hukum Internasional-Faculty of law, Universitas Indonesia, page 178.

21 Eddy Pratomo, "Prospek dan Tantangan Hukum Internasional di ASEAN dan Indonesia Pasca Piagam ASEAN dari Sisi Perjanjian Internasional", Jurnal Hukum UII, Vol. 16 Issue 1, 2009, Yogyakarta: Faculty of Law, Universitas Is-lam Indonesia, page 63.

22 Tyra Ruth Saechao, "Natural Disasters and the Responsibility to Protect: From Chaos to Clarity", Brooklyn Journal of International Law, Vol. 32 Issue 2, 2007, New York: Brooklyn Law School, page 673. 
Table 1. The Impact of Natural Disaster in the World based on Region 1984-2013

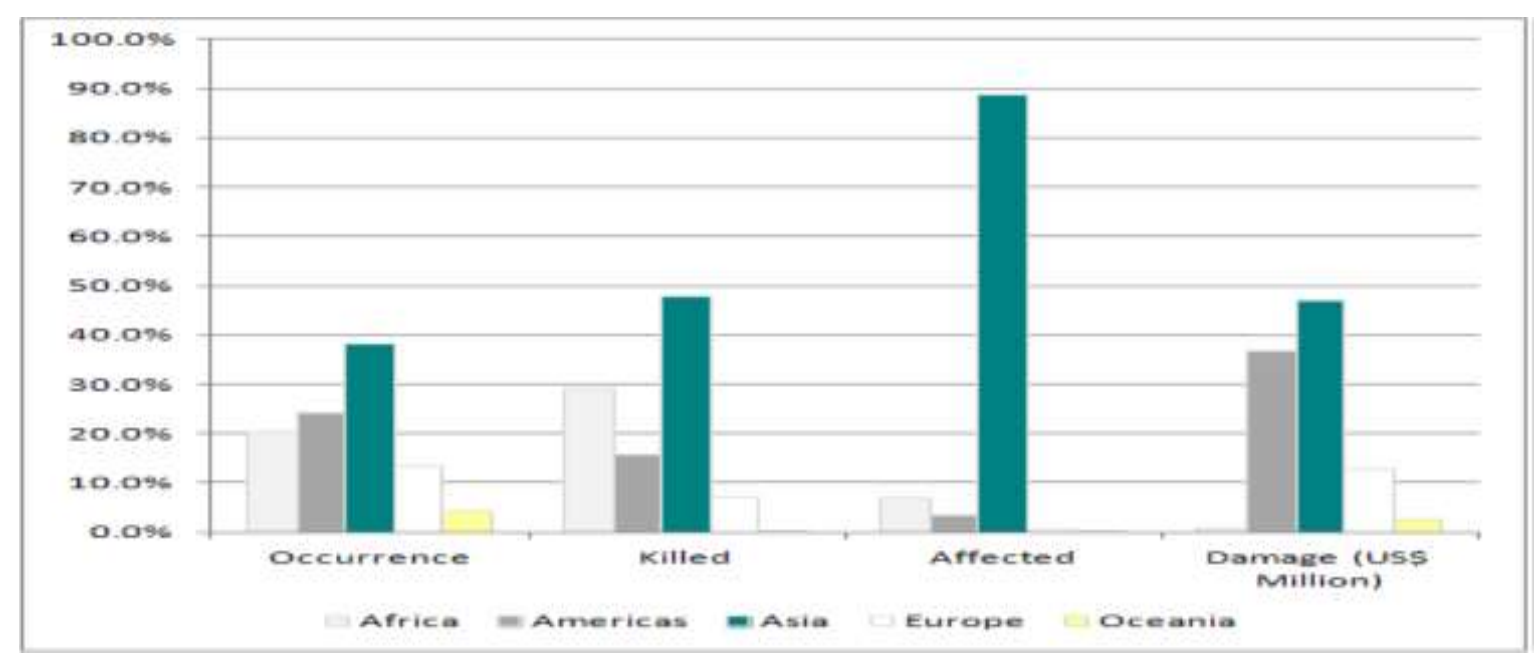

Table 2. The Impact of Natural Disaster based on Region 1984-2013

\begin{tabular}{|crrrrrrrr}
\hline & \multicolumn{10}{c}{ Impact } \\
\cline { 2 - 10 } Region & \multicolumn{2}{c}{$\begin{array}{l}\text { Occurrence } \\
\text { (share in \%) }\end{array}$} & \multicolumn{2}{c}{$\begin{array}{c}\text { Klled } \\
\text { (share in \%) }\end{array}$} & \multicolumn{2}{c}{$\begin{array}{c}\text { Affected } \\
\text { (share in \%) }\end{array}$} & \multicolumn{2}{c}{$\begin{array}{c}\text { Damage (USS million) } \\
\text { (share in \%) }\end{array}$} \\
\hline Africa & 2,099 & $(20.2 \%)$ & 726,996 & $(29.3 \%)$ & $423,894,194$ & $(7.0 \%)$ & 19,064 & $(0.8 \%)$ \\
Americas & 2,495 & $(24.0 \%)$ & 389,148 & $(15.7 \%)$ & $204,811,734$ & $(3.4 \%)$ & 916,177 & $(36.8 \%)$ \\
Asia & 3,952 & $(38.1 \%)$ & $1,186,437$ & $(47.7 \%)$ & $5,396,306,705$ & $(88.7 \%)$ & $1,169,341$ & $(47.0 \%)$ \\
Europe & 1,398 & $(13.5 \%)$ & 176,505 & $(7.1 \%)$ & $35,344,415$ & $(0.6 \%)$ & 320,256 & $(12.9 \%)$ \\
Oceania & 432 & $(4.2 \%)$ & 5,753 & $(0.2 \%)$ & $20,431,165$ & $(0.3 \%)$ & 64,662 & $(2.6 \%)$ \\
\hline Total & 10,376 & $(100.0 \%)$ & $2,484,839$ & $(100.0 \%)$ & $6,080,788,213$ & $(100.0 \%)$ & $2,489,499$ & $(100.0 \%)$ \\
\hline
\end{tabular}

Source : Data EM-DAT: The OFDA/CRED International Disaster Database, available on website: http://emdat.be/human_lost_natdis, accessed on November $12^{\text {th }}, 2016$.

protection needed by the victims. ${ }^{23}$ In response, the existence of a neutral international organization is the best option to distribute the humanitarian assistance or assistance.

The natural disaster management undertaken by ASEAN is divided into three stages, which are; pre-disaster, whilst-disaster, and post-disaster. Despite the absence of integrated and permanent binding force international rule, ASEAN has tried to arrange the rules on natural disaster management in the ASEAN region as follows:

23 Sigit Riyanto, “Intervensi Kemanusiaan Melalui Organisasi Internasional untuk Memberikan Perlindungan dan Bantuan Kemanusiaan kepada Pengungsi Internal: Debat tentang Urgensi dan Kendalanya", Jurnal Mimbar Hukum, Vol. 19 Issue 2, June 2007, Yogyakarta: Faculty of Law UGM, page 234.
(1) ASEAN Agreement on Disaster Management and Emergency 2005, enter into force 2009;

(2) ASEAN Declaration on Mutual Assistance on Natural Disasters, Manila, June $26^{\text {th }} 1976$;

(3) Declaration on Action to Strengthen Emergency Relief, Rehabilitation, Reconstruction and Prevention on the Aftermath of Earthquake and Tsunami Disaster of December $26^{\text {th }} 2004$;

(4) The ASEAN Agreement on Transboundary Haze Pollution of 10 June 2002

(5) The ASEAN Agreement for the Facilitation of Search for Aircrafts in Distress and Rescue of Survivors of Aircraft Accidents of 14 April 1972;

(6) The ASEAN Agreement for the Facilitation of Search of Ships in Distress and Rescue of Survivors of Ship Accidents of 15 May1975; 
(7) The Agreement on the ASEAN Food Security Reserve of 4 October 1979. ${ }^{24}$

\section{ASEAN Implementation and Role in Natural Disaster Management in Southeast Asia Region}

From the afore-mentioned rules, one of the most important thing in natural disaster management in ASEAN is the issue of ASEAN Agreement on Disaster Management and Emergency Response (AADMER) as an international agreement on disaster management in ASEAN. This Agreement binds ASEAN member countries to coordinate and cooperate in the response to natural disasters in ASEAN. ${ }^{25}$ To implement this function, ASEAN has established ASEAN Coordinating Center for Humanitarian Assistance on Disaster Management (AHA Center) that coordinates the natural disaster management in ASEAN. AADMER came into effect in 2009. The main mission of AADMER is coordination among member countries. ASEAN as an international organization that separates from its member countries functions as the coordinator. In this role, the principle of state sovereignty can be implemented simultaneously with the principle of human rights.

At the Tsunami disaster in 2004, ASEAN was still guided by the ASEAN Declaration. From 1967 to 2008, the interaction of ASEAN countries was based on the Bangkok Declaration or the ASEAN Declaration which is essentially a political statement that does not bind the rights and obligations of its member countries and organizations on the basis of law/constitution. Under these conditions, all the laws established and issued by ASEAN are included in the field of natural disaster management which is soft law and has no force power. Therefore, when the tsunami struck Southeast Asia and its member

24 Porntip (Ploy) Israsena na Ayudhya, "Potential Policies and Areas of Cooperation on Disaster Management and Emergency Response between ASEAN and Canada", available on website http://www.mfa.go.th/asean/ contents/files/asean-media-center-20130715-161750794058.pdf, accessed on December $12^{\text {th }}, 2013$. Also see http://www. asean.org/PR-AADMER-EIF-End-2009.pdf, accessed on November $1^{\text {st }}, 2013$.

25 Heribertus Jaka Triyana, "ASEAN dan Penguatan Rule of Law Hukum Hak Asasi Manusia di Kawasan Asia Tenggara”, Jurnal Opinio Juris, Vol.15, January-April 2014, Jakarta: Ministry of Foreign Affairs of Republic of Indonesia, page 83 . countries struggled to overcome it, ASEAN has no power at all.

In 2008, at the time of Hurricane Nargis sweeping Myanmar, the region was being stricken by armed conflict. Military Junta as the ruler at that time rejected the humanitarian assistance offered by outsiders. ${ }^{26}$ The worrying condition of the victims made countries outside the region including Britain, the United States planned to do military intervention to provide humanitarian assistance. In order to prevent intervention from outsiders that clearly against the values adopted by ASEAN countries, ASEAN leaders took the initiative to bridge the process of providing humanitarian assistance from outsiders to Myanmar. ${ }^{27}$ This method was accepted by both parties and became an ASEAN milestone to accelerate the process of the ASEAN agreement on disaster management. Although it was too late, ASEAN's responsive action becomes a reference for the next ASEAN policy in managing natural disaster as stated in the ASEAN agreement on natural disaster management.

In 2013, Haiyan Hurricane struck Philippines region had become a tester for ASEAN's role through the AHA Center in managing natural disasters after the release of AADMER. Although in practice the role of ASEAN is like a back-up plan, it is in accordance with what is stated by Daniel Petz,

"the fact that much of the humanitarian assistance from ASEAN countries have still the Philippines via bilateral channels, rather than through ASEAN and the coordination function of ASEAN in that respect". ${ }^{28}$

\section{Conclusion}

The State is the main actor which has full sovereignty in the process of natural disaster management that occurs in its country based on

26 Heath, J.Benton, "Disaster, Relief and Neglect: The Duty to Accept Humanitarian Assistance and the Work of the International Commission", Journal of International Law and Politic, Vol. 4, Issue 2, 2011, New York: New York University, page 421.

27 Karin LOEVY, "the Legal Politics of Jurisdiction: Understanding ASEAN's Role in Myanmar's Disaster, Cyclone Nargis (2008), Asian Journal of International Law, Vol. 1 Issue 1, 2015, Singapore: The National University of Singapore, pages 75-76.

28 Daniel Petz. Op.Cit. page 24. 
the principle of primary state responsibility. On the other hand, the inability or unwillingness of a country in managing the natural disasters in its territory cannot be a justification or forgiveness for refusing humanitarian assistance from other parties. ASEAN as a regional-international organization is located in areas which is tend to stricken by natural disaster, is considered more flexible in responding the different principles of humanitarian assistance. ASEAN through the AHA Center can accommodate the interests/ sovereignty of its member countries by not abandoning the fulfillment of the human rights of natural disaster victims. Nevertheless, the role of ASEAN coordinator is still inadequate because ASEAN has not have strong legitimacy as an independent international organization and is distinguished from its member countries which has the right to implement its own authority.

\section{References}

Anshari, Natsri. "Harmonisasi Hukum Internasional dan Hukum Nasional dalam Bantuan Kemanusiaan dan Penanggulangan Bencana Alam". Jurnal Hukum Militer. Vol.1. Issue 7. 2013. Jakarta: Pusat Studi Hukum Militer-Sekolah Tinggi Hukum Militer;

Ayudhya, Porntip (Ploy) Israsena na. 2013. "Potential Policies and Areas of Cooperation on Disaster Management and Emergency Response between ASEAN and Canada". Available on website http://www. $\mathrm{mfa}$.go.th/asean/contents/files/aseanmedia-center-20130715-161750-794058. pdf. accessed on December 12th, 2013;

EM-DAT, The OFDA/CRED International Disaster Database. Available on website http:// emdat.be/human_lost_natdis. Accessed on October $12^{\text {th }}, 2016$;

Belanger, Julie and Horsey. Richard. "Negotiating Humanitarian Access to Cyclone-Affected Areas: a Review". Humanitarian Practice Network Journal. Issue 41. December 2008. United Kingdom: Humanitarian Policy Group;

Benton, Heath. J. "Disaster. Relief and Neglect: The Duty to Accept Humanitarian Assistance and the Work of the International Commission". Journal of International
Law and Politic. Vol. 4 Issue 2. 2011. New York: New York University;

Chesterman, Simon. "Does ASEAN Exist? The Associaton of Southeast Asian Nations as an International Legal Person". Singapore Year Book of International Law (SYBIL) Journal. Issue 12. 2010. Singapore: The National University of Singapore;

Chalermpalanupap, Termsak. "The ASEAN Secretariat and Legal Issues Arising from ASEAN Charter". Jurnal Hukum Internasional. Vol. 6 Issue 2. 2009. Depok: Lembaga Pengkajian Hukum Internasional Faculty of Law Universitas Indonesia;

Emmerson, Donald K. "Security. Community. and Democracy in Southeast Asia: Analyzing ASEAN". Japanese Journal of Political Science. Vol. 6. Issue. 2008. United Kingdom: Cambridge University Press;

Farida, Elfia. "Efektivitas Piagam ASEAN (ASEAN Charter) bagi ASEAN sebagai Organisasi Internasional". Jurnal QISTIE. Vol. 3 Issue 3. 2009. Semarang: Faculty of Law Universitas Wahid Hasyim;

Ferris, Elizabeth and Daniel Petz. "In the Neighborhood: the Growing Role of Regional Organizations in Disaster Risk Management". the Brooking Institution-London School of Economics Project on Internal Displacement. 2013. United Kingdom: the Brooking Institution-London School of Economics;

Fischer, Peter. 2012. "International Organization". Vienna Bratislava. available on http://paneurouni.com/files/sk/fp/ulohy -studentov/2rocnikbc/io-skript.1.10.20 12.new-version.pdf. Accessed on October $28^{\text {th }}, 2013$;

Guan, Benny Teh Cheng. "ASEAN's Regional Challenge: the ASEAN Process". the Copenhagen Journal of Asian Studies. Vol. 20. 2004. Denmark: Asia Research CenterCopenhagen Business School;

Haver, Katherine and Conor Foley. "International and Regional Initiatives". Background paper 2 prepared for the International Dialogue on Strengthening Partnership in Disaster Response. October 2011. available on website http://www.ifrc. org/PageFiles/93533/Background\%20pape r\%202.pdf. accessed on November $5^{\text {th }}$, 2014.

Hicken, Allen. "The Philippines in 2008: Peace Building. War-Fighting. and Crisis Manage- 
ment". Asian Survey Journal. Vol. 49 Issue 1. January/February 2009.USA: University California Press;

Hilhorst, Dorothea and Bram J Jansen. "Humanitarian Space as Arena: A Perspective on the Everyday Politics of Aid". Development and Change Journal. Vol. 41 Issue 6. November 2010. The Hague: International Institute of Social Studies;

Huard, Ian. "Choice and Methods in the Study of International Organizations". Journal of International Organizations Studies. Vol. 2 Issues 2. 2011. United States of America: Brigham Young University-Kennedy Center.

Triyana, Heribertus Jaka. "ASEAN dan Penguatan Rule of Law Hukum Hak Asasi Manusia di Kawasan Asia Tenggara”. Jurnal Opinio Juris. Vol. 15. January-April 2014. Jakarta: Indonesia Ministry of Foreign Affairs;

LOEVY, Karin. "the Legal Politics of Jurisdiction: Understanding ASEAN's Role in Myanmar's Disaster. Cyclone Nargis (2008)". Asian Journal of International Law. Vol. 1 Issue 1. 2015. Singapore: The National Univer-sity of Singapore;

Lombok, Lesza Leonardo. "Kedaulatan Negara vis a vis Keistimewaan dan Kekebalan Hukum Organisasi Internasional dalam Sebuah In-tervensi Kemanusiaan". Jurnal Pandecta. Vol. 9. Issue 1. January 2014. Semarang: Universitas Negeri Semarang;

Petz, Daniel. November 2014. "Strengthening Regional and National Capacity for Disaster Risk Management-the Case of ASEAN". Brooking LSE Project on Internal Displacement. Brooking Institution. Available on website http://www.brookings. edu/ /media/research/files/reports/201 4/11/05-south-east-asia-drmpetz/streng thening-regional-and-national-capacityfor-drm--case-of-asean-november-5-2014. pdf. Accessed on August $4^{\text {th }}, 2015$.

Pratomo, Eddy. "Prospek dan Tantangan Hukum Internasional di ASEAN dan Indonesia Pasca Piagam ASEAN dari Sisi Perjanjian Internasional". Jurnal Hukum UII. Vol. 16 Issue 1. 2009. Yogyakarta: Faculty of Law Universitas Islam Indonesia.

Riyanto, Sigit. "Intervensi Kemanusiaan Melalui Organisasi Internasional untuk Memberikan Perlindungan dan Bantuan Kemanusiaan kepada Pengungsi Internal: Debat tentang Urgensi dan Kendalanya". Jurnal Mimbar Hukum. Vol. 19 Issue 2. June 2007. Yogyakarta: Faculty of Law Universitas Gadjah Mada;

Saechao, Tyra Ruth. "Natural Disasters and the Responsibility to Protect: From Chaos to Clarity". Brooklyn Journal of International Law. Vol. 32 Issue 2. 2007. New York: Brooklyn Law School;

SIMM, Gabrielle. "Disaster Response in Southeast Asia: the ASEAN Agreement on Disaster Response and Emergency Management". Asian Journal of International Law. doi: 10.1017/S2044251316000205. 2016. Singapore: the National University of Singapore;

Suominen, Kati. 2005. "Globalizing Regionalism: Harnessing Regional Organizations to Meet Global Threats". UNU-CRIS Occasional Papers. available on website http:/ / www.cris.unu.edu/UNU-CRIS-Work ing-Papers. Accessed on November $5^{\text {th }}$, 2014. 